\title{
Contrast training in football and its effect on the performance of students in this field of education
}

\section{El entrenamiento de contraste en el fútbol y su efecto en el rendimiento de los estudiantes en este campo de estudio}

\author{
Sezgin Korkmaz \\ Burdur Mehmet Akif Ersoy University, Faculty of Sport Sciences, Burdur, Turkey \\ ORCID: https://orcid.org/0000-0002-2001-2741 \\ Hüseyin Şahin UYSAL \\ Burdur Mehmet Akif Ersoy University, Faculty of Sport Sciences, Burdur, Turkey \\ ORCID: https://orcid.org/ 0000-0002-3595-8812
}

* Correspondence 


\section{Summary}

Many factors determine success in football. But the most important of these are the physical and physiological variables that determine the performance of football players. Meeting these physical and physiological needs is also based on training methods prepared following branch-specific neural, muscular, and metabolic parameters. In football, for some reason, sufficient time cannot be allocated to the biomotor properties that need to be developed. Different methods are put forward to eliminate the obstacles that occur. One of these methods, which was discussed in the educational system of this field, was the idea of combining different strength training. Although there are different designs on these training in the literature, the most commonly studied methods are complex and contrast training. Complex and contrast training is based on the theory of post-activation potentiation, although there are minor differences between them. These methods generally include plyometric exercise followed by a severe strength exercise. For this reason, contrast and complex training are considered by some researchers as similar training methods, while studies that claim otherwise are also found in the literature. Discussions continue in terms of training protocols and training terms which are used. These methods are investigated by experts with many different protocols when the literature is examined. Confusion in the literature also affects studies on football. Complex and contrast training protocols in football that are used to define the purpose of this study, to examine the effect on player performance, on methods to deal with developments and discussions with existing methods to evaluate the positive and negative aspects to provide a critical perspective on sensible recommendations.

Keywords: Complex training, Contrast training, PAP, Football, Educational system improvement

\section{Resumen}

Muchos factores determinan el éxito en el fútbol. Pero las más importantes son las variables físicas y fisiológicas que determinan el rendimiento de los futbolistas. Satisfacer estas necesidades físicas y fisiológicas también se basa en métodos de entrenamiento preparados siguiendo parámetros neuronales, musculares y metabólicos específicos de cada rama. En el fútbol, por alguna razón, no se puede dedicar suficiente tiempo a las propiedades biomotoras que deben desarrollarse. Se proponen diferentes métodos para eliminar los obstáculos que se presentan. Uno de estos métodos, que fue discutido en el sistema educativo de este campo, fue la idea de combinar diferentes entrenamientos de fuerza. Aunque existen diferentes diseños sobre este entrenamiento en la literatura, los métodos más comúnmente estudiados son el entrenamiento complejo y de contraste. El entrenamiento complejo y de contraste se basa en la teoría de la potenciación posterior a la activación, aunque existen pequeñas diferencias entre ellos. Estos métodos generalmente incluyen ejercicio pliométrico seguido de un ejercicio de fuerza severo. Por esta razón, algunos investigadores consideran el contraste y el entrenamiento complejo como métodos de entrenamiento similares, mientras que los estudios que afirman lo contrario también se encuentran en la literatura. Continúan las discusiones en cuanto a los protocolos de formación y los términos de formación que se utilizan. Estos métodos son investigados por expertos con muchos protocolos diferentes cuando se examina la literatura. La confusión en la literatura también afecta a los estudios sobre fútbol. Protocolos de entrenamiento complejos y contrastantes en el fútbol que se utilizan para definir el propósito de este estudio, examinar el efecto sobre el rendimiento del jugador, sobre métodos para lidiar con desarrollos y discusiones con métodos existentes para evaluar los aspectos positivos y negativos para proporcionar una perspectiva crítica sobre recomendaciones sensatas.

Palabras clave: Entrenamiento complejo, Entrenamiento de contraste, PAP, Fútbol, Mejora del sistema educativo 


\section{Introduction}

Football is one of the most popular sports branches played for centuries and has become one of the largest industries in the world in recent years (Roussos, 2019; Shephard, 2015). An increase in interest in football leads to an increase in material and spiritual investments in the industry (Dobson et al., 2001). These investments, on the other hand, constitute an environment of expectation and competition for success by every segment interested in football. Many factors determine success in football. But the most important of these are the physical and physiological variables that determine the performance of players on the field (Mishra \& Rathore, 2016). Maximum physical readiness is needed to reflect the technical and tactical strategies designed by the coaches on the field and win the competition. Meeting these physical needs is also based on training methods prepared in accordance with branch-specific neural, muscular, and metabolic parameters (Walker, 2016; Ferley et al., 2020). Reviewing the needs analysis of the branch is an important step in achieving success when designing a training program. Given the duration of the competition and the distances traveled, football is an aerobic-based and endurance-demanding branch. From this point of view, football can be defined as a long-term, intermittent, and high-intensity sports branch (Rampinini et al., 2010). But this definition is insufficient for football. Football also includes many anaerobic-based activities. These activities are stated numerically, a player in a match, 90 minutes running average 10-12 km near the anaerobic threshold (Stølen et al., 2005), the average return during a match to make 700 (Bloomfield et al., 2007), each ranging from 10 to 30 feet is performing sprints in 90 seconds (Stølen et al., 2005). Moreover, many short-term explosive activities such as sudden interventions, shots, and jumps are involved in football. For the development of these movements, the development of strength, which also forms the basis of different biomotor abilities, is essential. Football is played at higher speeds every day, and athletic performance becomes more important in branches such as football (Kobal et al., 2017). In this sense, many scientists express that strength and strength development are as important as endurance for football (Jovanovic et al., 2011; Thomas et al., 2009; Turner et al., 2011).

The development of strength in football is divided into several phases. In this respect, strength development is achieved by maximal strength studies following anatomical adaptation, followed by strength training involving branch-specific transformation (Eniseler, 2017). But several factors prevent the natural development of this process. While an athlete needs an average of 3 months of preparation to be ready for competitions (Bompa \& Buzzichelli, 2018), the inability to meet this need due to the length of a football season is seen as a factor. Another factor is that unit training allocated for athletic performance development due to the intensity of the fixtures at the competition stage is insufficient to develop these motor capabilities (Mujika et al., 2009). Different methods are put forward to eliminate the obstacles that occur. One of these methods was the idea of combining different strength training. Comett, who had a large share in the development of combined strength training, argued that strength training should provide a transformation between the resulting strength and the technical characteristics of the sports branch (García-Pinillos et al., 2014). The idea put forward many years ago has become a method that is often studied and practiced today. The positive effect of combined strength training on performance has been confirmed by numerous studies (Latorre Román et al., 2018; Lagrange et al., 2020; Franco-Márquez et al., 2015). Although there are different designs on these training in the literature, the most commonly studied methods are complex and contrast training. Complex and contrast training is based on the theory of post-activation potentiation, although there are minor differences between them. However, in the literature, it is generally defined as a plyometric exercise biomechanically similar to that exercise following a classic strength exercise in the same training (Cormier et al., 2020). The only difference is the order of application of strength exercises and plyometric exercises. With these methods, many parameters, especially strength, sprint, and jump, can be developed together (Cormier et al., 2020). The joint development of different abilities brings many advantages to coaches and athletes.

According to our information, there are no compilation studies in the literature that address the performance impact of contrast and complex training on footballers. In this direction, the study aims to examine the complex and contrast training methods used in football and to evaluate the positive and negative aspects of the methods from a critical point of view. 


\section{Method}

This study is to review research.

\section{Results}

\section{Relationship between football and strength}

Football is a sports branch in which strength-based activities such as dual fights, short and mediumdistance sprints, jumps, and shooting are constantly practiced over a certain period (Turner \& Stewart, 2014). The game structure of football is accelerating every day and becoming based on high violence. This changes the physiological and morphological demands of the branch but highlights the need for strength. Researchers believe that strength is the most important biomotor ability for the development of athletic performance (Suchomel et al., 2016). It is stated by studies that strength training has a greater effect than running training to improve jump and sprint performance (Silva et al., 2015) and that the development of these abilities, including aerobic endurance, is directly proportional to strength development (Turner \& Stewart, 2014). The importance of strength for football is not limited to them. A study conducted by Edge et al. (2006) concluded that weight training has a positive effect on performance parameters such as repeated sprint and change direction. The results showed that strength training also provided a physiological advantage. As a result of the study, there was a decrease in the collected hydrogen ions in the novelties, and the lactate threshold of the subjects developed (Edge et al., 2006). Substances responsible for fatigue, such as lactate and hydrogen, can improve with strength training, allowing individuals to get tired later in the competition. These effects also reveal the indirect effect of strength training on aerobic capacity. When all results are considered, strength training and strength development are an indispensable element for football. Applying the correct weight training to the studied population, season and purpose is the basis for improving athletic performance in football.

\section{Contrast and Complex Training Approaches}

When we review the literature, it seems that there is a confusion of concepts to describe contrast and complex training. The reason for the complexity is based on the point of origin of these methods. The foundation of Complex and contrast training was laid in 1966 by the Russian scientist Verkhoshansk. Verkhoshansk, who designed a training method by combining different strength training, did not give a name to the training method he created, so there were uncertainties in the following years (Übellacker, 2017). Combined strength training was applied in different terms as contrast training, complex training, compound training, combined training (Alves et al., 2010; Stasinak et al., 2015; Zghal et al., 2019). The first researchers to use the term complex training in the literature were Fleck and Kontor in 1986. Fleck and Kontor (1986) defined complex training as applying a set block plyometric exercise biomechanically similar to this strength exercise after a set block strength exercise. According to Fleck and Kontor, who share eight different complex training protocols related to the description, performing a 2-set low-intensity squat jump movement after a 2 -set high-intensity squat exercise is an example complex training protocol. Besides, researchers noted that complex training will not only be performed with low-intensity plyometric exercises after high-intensity exercise but also exercises with bodyweight after high-intensity exercise will also be suitable for complex training (Fleck \& Kontor, 1986).

On the other hand, the first name to express the concept of contrast training was probably Baker in 1995. In this study, Baker (1995) defined the contrast method as opposite exercises and loads in which strength and speed are combined. He mentioned two different methods of contrast training, such as the Russian style and the Bulgarian style, which were popularly used at the time. According to Baker, plyometric exercise sets after high-intensity strength exercise sets are Russianstyle contrast training. Fleck and Kontor used complex training for the same training protocol (Fleck \& Kontor, 1986). Bulgarian-style contrast training, on the other hand, is expressed as a method in which high-intensity activities are gradually reduced and the speed of movement is increased (Baker, 1995). Following these designations, in 1998, in the study of Young et al. complex training was 
expressed as plyometric sets made after intensive loading sets. Contrast training is defined as applying a set of plyometric exercises after a set of intense loads. At the same time, researchers have suggested that these two methods are similar in terms of the loads used (Young et al., 1998). In terms of contrast training, different researchers in the following years also mentioned protocols and definitions similar to the definition of Young et al (Kobal et al., 2017; García-Pinillos et al., 2014; Latorre Román et al., 2018; Duthie et al., 2002). But contrast and complex have been made in different definitions for training. In one of these studies, 3 different one-set exercises called complex contrast training were applied consecutively. (Alves et al., 2010). Moreover, studies have also been conducted claiming that complex training is the practice of a single-set plyometric exercise after a single-set strength exercise (Ebben, 2002; Docherty et al., 2004). To eliminate the confusion of concepts in a current study, Übellacker has put forward a different perspective. According to this point of view, all training methods created by combining different strength training are defined as complex training. Complex training is divided into various classes such as contrast load, block contrast load, combined load according to the order of strength, and plyometric exercises (Übellacker, 2017).

When the literature is examined, it is worth noting that there is disagreement in defining training methods. However, it seems that the training protocols or definitions of some of the most cited studies in the literature on this topic are similar to the first studies on contrast and complex training (García-Pinillos et al., 2014; Duthie et al., 2002; Santos \& Janeira, 2008; Mihalik et al., 2008; Ingle et al., 2006). Explaining training methods through pioneering studies and the most cited research in the literature can be an approach to making the correct definition. Based on this inference, contrast training is to apply a set of low-intensity plyometric exercises biomechanically similar to this exercise after a high-intensity set of strength exercises. Complex training consists of a highintensity set block (E.g. 2 or 3 sets) is a low-intensity plyometric exercise consisting of a set block biomechanically similar to this exercise after a strength exercise. In this study, one-set strength/plyometric exercise applications will be considered as contrast training, strength/plyometric exercise applications between sets will be considered as complex training to avoid concept confusion.

\section{Contrast and Complex Training Protocols Applied in Football}

In various studies, there are different definitions related to contrast and complex training. Although the explanations for the two training methods are contradictory, all researchers argue that these training methods should first be performed with a high-intensity exercise, and then with a lowintensity exercise. But how training methods are applied is also not limited to classical definitions. Some contrast and complex training protocols applied in football can be classified as;

High intensity following low-intensity contrast training: This protocol is the most studied type of contrast training in the literature. A sample study was conducted by Kobal et al. (Kobal et al., 2017). In this study, the effect of 8 weeks of contrast training, complex training, and traditional strength training on performance was investigated. The plyometric exercise set followed the medium-high intensity exercise set in the training protocol, while the 3-set strength exercise in the complex training protocol was followed by 3 -set plyometric exercises. In traditional strength training, 3 sets of plyometric exercises and 3 sets of strength exercises were performed first. In the process, the scope and intensity of training varied (Kobal et al., 2017).

Plyometric exercise and contrast training following isometric exercises: Another contrast training protocol applied to footballers in the literature is plyometric exercises following an isometric exercise. A study following this protocol was conducted by García-Pinillos et al (García-Pinillos et al., 2014). For 12 weeks, the experimental group applied the contrast training protocol consisting of 1 isometric and 2 plyometric exercises. During the process, increases and decreases in the scope and intensity of training were included. 
Complex training involving branch-specific movements following high-intensity exercises: Complex training protocols created specifically for football have also been studied by researchers. The work of Cavaco et al. can be given as an example of this protocol (Cavaco et al., 2014). The protocol consists of 8 weeks, including 2 weeks of adaptation, 6 weeks of complex training. Exercises were performed at 2 stations. At the first station, footballers worked a maximum speed of 15 meters in addition to 6 repeat squats with $85 \%$ of $1 \mathrm{TM}$ (maximum repeat). In the study, 3 minutes of rest were applied. At the second station, in addition to the same repeat, set and intensity squat exercise, agility with the ball and smash with the goal were performed. In the study, 3 minutes of rest were applied. It was not specified which exercise or repetitions were given after the rest breaks. Squat loads were increased by $5 \%$ of 1 TM every two weeks.

Complex training specific to the physiological needs of the branch: Arguing that the anaerobic system is dominant when applying the complex training method and that lactate tolerance can be improved with the necessary additions, Treeraj et al., (2016) have created a new complex training protocol following the physiological demands of the football branch. The study was applied in 3 groups. In this protocol, subjects performed a plyometric exercise set and a sprint study after a high-intensity strength exercise set. Rest periods differed between groups. Set numbers were not specified in the study.

\section{Theoretical Approach to Contrast and Complex Training: Post-Activation Potentiation}

The history of the concept of potentiation dates back to the 19th century. This concept describes the increase in strength through physiological changes in the organism after a severe pre-activity and it is stated that it can occur in 3 different forms (Blazevich \& Babault, 2019). Forms are staircase potentiation (SP), post-tetanic potentiation (PTP), and post-activation potentiation in order of occurrence. The difference that distinguishes potentiations is the way electrical impulses are generated to make novelization occur. As a matter of fact, in SP, the increase in strength occurs gradually, with repetitive and low-frequency electrical stimuli (Rassier et al., 1999). On the other hand, the increase in strength in PTP is caused by high-intensity and involuntary tetanic neural stimuli (Blazevich \& Babault, 2019; Tillin \& Bishop, 2009). Post-activation potentiation (PAP) is an increase in the number of electrical stimuli as a result of natural activation at repetitive frequencies. An acute increase in strength and strength occurs after a voluntary novelization of the muscle with or near the maximum with PAP (Seitz \& Haff, 2016). No matter what form the potentiation takes, it creates an increase in strength after the preliminary activity.

Contrast and complex are based on the theory of post-activation potentiation, a form of potentiation in training. The theory is also expressed in the literature as PAP can occur with involuntary muscle contractions, as well as with involuntary contractions using external stimuli (Seitz \& Haff, 2016; Requena et al., 2005). It is suggested that several physiological mechanisms are involved in the formation of the PAP effect. In the first place, 3 basic mechanisms are mentioned, while today it is claimed that 4 different mechanisms can form the PAP effect (Pajerska et al., 2020). The first of these mechanisms is myosin light chain phosphorylation. Myosin is a protein that is responsible for muscle contraction and performs muscle contraction by pulling actin flamentine onto it. The myosin molecule consists of two heavy chain heads. In the body of these heavy chains, there are two regulatory light chains. Light chains can also contain phosphate molecules that change the structure of the myosin head (Blazevich \& Babault, 2019; Tillin \& Bishop, 2009; Hodgson et al., 2005). At the same time, the myosin heads have actin and an ATP binding point. Myosin light chain phosphorylation is activated by an enzyme called MLCK. This enzyme stimulates the regulatory light chains and induces a change in the myosin head. On the other hand, sensitivity to the CA+ ion increases, and as a result, a strength shot occurs with stronger contractions. It is also noted that the resulting increase in strength is more intense in individuals with Type II novelties (Blazevich \& Babault, 2019; Tillin \& Bishop, 2009; Hodgson et al., 2005). The two theories that make up the PAP effect are thought to be changes in neural activities known as the H-reflex. In this theory, vigorous exercise increases the level of volitional neural impulses to the muscles by increasing the rate of maximal muscle strength and muscle strength development (Heckman \& Enoka, 2012). It is stated that such a change will reduce the level of excitability in the spinal cord (Nuzzo et al., 2016). As a result of the changes, it can be predicted that there will be an increase in the number of engine units 
participating in the movement. The first two theories are thought to have had a large share in the formation of the PAP effect. However, some studies suggest that changes in muscle pennate angle will affect Pap (Tillin \& Bishop, 2009) and that physiological changes between titin protein and actin will contribute to Pap (Pajerska et al., 2020). In addition to existing mechanisms, other important issues are factors affecting Pap. Indeed, there is a fine line between PAP and fatigue. It increases in fatigue while potentiation increases after a high-intensity exercise. But fatigue ends prematurely, according to potentiation. Therefore, there is a potentiation phase in which athletes can increase their performance (Hodgson et al., 2005). This stage does not occur at the same time for each individual. Many factors such as exercises, training intensity, training history, sex, age, rest time, muscle contraction type, muscle fiber type, muscle length cause the PAP effect to occur at different times (Seitz \& Haff, 2016; Tsolakis et al., 2011; Shepherd, 2019; Karaday, 2018). Considering the elements that affect pap when designing a workout will bring maximum benefit from this theory.

\section{The Effect of Contrast and Complex Training on Sports Performance}

In the literature, one of the most studied populations of contrast and complex training is football players. Many parameters such as strength, sprint, agility, jump, and branch-specific technical driller have been the subject of research by experts (Kobal et al., 2017; Mujika et al., 2009; Cavaco et al., 2014; Hammami et al., 2019). In football, contrast and complex training research found no negative results in terms of performance. These exercises are known to be based on the PAP effect (Ali et al., 2019). Considering the presence of many factors affecting the formation of the PAP effect, it may be a logical approach to evaluate physical parameters based on elements such as exercise intensity, repetition numbers, exercise choices, and age. In the studies, the effect of contrast and complex training on performance was examined within 5 weeks to 12 weeks. The research was carried out mostly during the competition phase, with football players aged 13 to 25 forming groups of subjects. It is also worth noting that groups of subjects consist of male footballers (table.1; table.2).

In studies on contrast training, training protocols, usually consisting of isotonic novelties, were applied (Kobal et al., 2017; Hammami et al., 2019; Faude et al., 2013; Spineti et al., 2016). But it is present in studies where isometric novelization is applied (Roussos, 2019; 17). In one of these studies, Felipe García et al., applied the contrast training protocol 3 days a week for 12 weeks. At the end of the season, a positive significant difference was found in parameters such as sprint, jump, and agility for the contrast training group (García-Pinillos et al., 2014). A similar study was carried out by Roussos in the following years (Roussos, 2019). After a high-intensity half-squat exercise in which isometric contraction was included, the subjects underwent a drop jump exercise in a $40 \mathrm{~cm}$ box. In the study, which was conducted 2 days a week for 6 weeks, the subjects performed a total of 6 sets and 18 repeat protocols in each training unit. Between sets, 2 to 3 minutes of rest is given. As a result of the study, there was an increase in the reactive strength index and vertical jump ability of the experimental group (Roussos, 2019). Contrast training protocols, which include isotonic strength exercises, are designed in different ways than the training protocols included in the article. In the following years, a study by Faude et al found similar results in terms of agility and sprint (Faude et al., 2013). The researchers implemented a protocol called the multiple contrast training model 2 days a week. On the first day of the week, subjects performed 4 sets of 5 repeated plyometric exercises followed by 4 repeated one-leg squat exercises with $90 \%$ of 1 TM. 4 minutes of rest is given between sets. On the second day, 4 different combinations of exercises were performed, followed by plyometric exercises and sprints, with strength exercises ranging from 50-60\% of $1 \mathrm{TM}$. As a result of the study, no difference was found in parameters such as sprint, agility, and isometric power, while jump and strength increase occurred in the experimental group (Faude et al., 2013). In contrast to the sprint findings in these studies, Kobal et al. in one study, the contrast training protocol applied 2 days a week for 8 weeks had a positive effect on the jump and strength measurements of the subjects, including in sprint. In this article, the contrast training method is compared with complex training and traditional strength training in a study conducted following the recognition and protocol we have adopted for contrast training. A significant difference in sprint performance is observed in the contrast training group compared to other groups. But no significant difference was found in 
other characteristics studied (Kobal et al., 2017). Another study in which contrast training (CT) and traditional strength training (TST) are compared belongs to Spinet et al. (Spineti et al., 2016). The activities included in the protocol of this study differ from other studies. 1 set of plyometric jump exercises were performed between $60 \%$ and $100 \%$ of the type of violence specified as peak power, and 1 set of plyometric box jumps were performed after 3 minutes of rest. On a different training day, high-intensity classical strength exercises were followed by plyometric exercises. The TST group performed classic strength training. At the end of the study, there was a significant increase in the sprint, strength, and jump parameters of the CT Group (Spineti et al., 2016). In later years, Hammami et al. who studied many topics in this field achieved similar results (Hammami et al., 2019; Hammami et al., 2017a; Hammami et al., 2017b). In 2017, the researchers investigated the 8 -week effect of contrast training in different subjects. In these studies, subjects performed half a squat between $70 \%$ and $90 \%$ of the 1 maximum repetition as a strength exercise, followed by a plyometric jump exercise and a 15 -meter sprint. As a result of the study comparing contrast training and the control group, sprint tests at various distances did not find a significant difference in repeated speed tests, although there was a significant difference in repeated change of direction and agility tests (Hammami et al., 2017a). In a study comparing contrast training, TST, and the control group, there was a significant increase in agility and jump parameters in different sprint tests, except for the repeated sprint test (Hammami et al., 2017b). A study conducted by Al-Shafee in the same year suggested that the strength and sapping performance of subjects improved with 10-week CT (AlShafee, 2017). 2 years later, Hammami et al. (2019) compared the CT, plyometric training, and control group with the same training protocol. A significant difference in sprint, strength, jump, and agility parameters occurred after the test for the CT group. A significant difference occurred in some parameters between the CT Group and the plyometric training group, while no significant difference was found in some (Hammami et al., 2019. A study conducted by Sahir found that although 12 weeks of contrast training during the season improved agility, speed, quickness, and agility were insufficient in the face of training (Sahir, 2019). Although some studies claim that contrast training improves agility (García-Pinillos et al., 2014; Sahir, 2019), some studies have found no positive effect (Kobal et al., 2017; Mujika et al., 2009).

Complex training designs also have different protocols, while the results are more controversial in terms of the characteristics investigated than contrast training. In one of the studies conducted, Ronnestad et al. compared complex training, TST, and control group (Ronnestad et al., 2008). The TST group performed squat and hip flexion exercises between 3-5 sets and 4-6 repetitions, while the complex training group performed 3 different plyometric exercises after strength exercises between 2-4 sets and 5-10 repetitions. As a result of the experiment, there was a significant difference in strength and some jump parameters, while there was no significant difference in sprint and squat jump parameters (Ronnestad et al., 2008). One thing researchers were curious about was finding the most appropriate frequency of training on the subject. Maio Alves et al. prepared a 6-week complex training protocol (Alves et al., 2010). This protocol included 3 stations and 3 movements at each station. As the first exercise of each station, strength exercises with intensity ranging from $80-90 \%$ of $1 \mathrm{TM}$ were performed, while plyometric jumps and sprint exercises were performed at the second and third stations. In the study, the effect of complex training 1 and 2 days a week was also questioned by the researchers. While an increase in sprint performance was observed as a result of the experiment, no significant difference was found in some jump tests and agility tests. Besides, there was no significant difference between training 1 or 2 days a week for this protocol (Alves et al., 2010). In the following years, similar results were reported by Brito et al. Based on the training program created by Maio Alves et al., Brito et al. investigated the effect of complex training, plyometric training, traditional strength training on performance. At the end of the 9 th week, there was no significant difference in agility, jump, and 5-meter sprint time, while only development was observed in 20-meter sprint time (Brito et al., 2014). In another study conducted by Harsley et al., the complex training (CoA) protocol was applied with $85 \%$ of 1 TM followed by 3 sets of strength exercises with plyometric or olympic lifts. After 10 weeks of work, no significant difference was found in the agility parameter when 40 meters of sprint time, vertical jump ability, and explosive strength improved with complex training (Harsley et al., 2015). In another study Wallenta et al. (2016) they examined the effect of complex training and block strength training in young German football players. In this study, subjects in the CoA protocol performed a 3-set 5repeat squat exercise with $60-70 \%$ of 1 TM. The squat exercise was followed by 3 sets of 3 repeated 
hurdle jump exercises. As a result of the study, there were no significant differences in various sprint parameters in the CoA group, while improvements in jump, agility, and strength parameters were observed. But the COA group was able to excel in the block strength training group only in the jump parameter (Wallenta et al., 2016). In the following years, two more studies were conducted that resulted in the final top of complex training in football (Abdelkader, 2018; Karabıyı, 2018). In one of the studies, Abdelkader (2018) applied an 8-week CoA protocol to a group of 10 subjects. In the first 3 weeks of the training protocol, 2 sets of high-intensity exercises were followed by 2 sets of plyometric exercises, while in the remaining 5 Weeks, 1 set of high-intensity exercises were followed by 1 set of plyometric exercises. As a result of the research, Abdelkader achieved significant differences in many jump-based parameters (Abdelkader, 2018). In a study similar to this training protocol, it was performed by Karabiy1k as a complex training. A 1 -set high-intensity strength exercise was followed by a 1-set plyometric exercise. A significant difference in jump, sprint, and agility parameters was found after a study conducted 3 days a week for 6 weeks (Karabıyık, 2018). In a study a few years ago, Chatzinikolaou et al., examined the effect of complex training in the transition phase. Subjects who practiced classic weight training two days a week practiced complex training, which included olympic lifts, plyometric exercises, and sprint exercises on the other two days. At the end of the study, various jump abilities, short-distance sprint tests, and maximal strengths of the subjects were improved. However, no significant difference in the longdistance sprint, repeat sprint, and agility parameters have been reached (Chatzinikolaou et al., 2018). In a study conducted by Ali et al., contrast and complex training were compared (Ali et al., 2019). For complex training, a 3-set plyometric exercise was performed following a 3-set high-intensity strength exercise. But in contrast to training protocol, unlike studies in the literature, first lowintensity sets and then high-intensity sets were performed. After the study, complex training was found to be more effective in improving agility, sprint, and jump abilities than contrast training. Detailed information about research in which physical parameters are evaluated in this review and is included in Table 1 and Table 2.

Table 1. The Effect of Contrast Training on Physical Parameters in Soccer

\begin{tabular}{|c|c|c|c|c|c|c|c|}
\hline Articles & Groups & $\begin{array}{l}\text { Subject } \\
\text { Type }\end{array}$ & Season & $\begin{array}{l}\text { Work } \\
\text { Time }\end{array}$ & $\begin{array}{l}\text { Researched } \\
\text { Parameters }\end{array}$ & $\begin{array}{c}\text { Cont } \\
\text { Tr. Test } \\
\text { Results }\end{array}$ & $\begin{array}{l}\text { Contrast Tr. Against } \\
\text { Other Groups the Effect }\end{array}$ \\
\hline \multirow{5}{*}{$\begin{array}{l}\text { Hammam } \\
\text { i et al } \\
2019(53)\end{array}$} & \multirow{5}{*}{$\begin{array}{l}\text { - Contrast } \\
\text { Tr. } \\
\text { - Plyometric } \\
\text { Tr. } \\
\text { - Control } \\
\text { Group }\end{array}$} & \multirow{5}{*}{$\begin{array}{c}40 \text { men's } \\
\text { footballer } \\
(15.8 \pm \\
0.4 \text { Age })\end{array}$} & \multirow[t]{5}{*}{ In-Season } & \multirow{5}{*}{$\begin{array}{c}8 \mathrm{wk} / 2 \\
\text { day }\end{array}$} & Sprint & $\uparrow$ & PT MO C CG $\uparrow$ \\
\hline & & & & & Vertical Jump & $\uparrow$ & $\mathrm{PT} \uparrow \mathrm{CG} \mathrm{MO} \uparrow$ \\
\hline & & & & & Leg Peak Power & $\uparrow$ & $\mathrm{PT} \uparrow \mathrm{CG} \mathrm{MO} \uparrow$ \\
\hline & & & & & $1 \mathrm{RM}$ & $\uparrow$ & $\mathrm{PT} \uparrow \mathrm{CG} \mathrm{MO} \uparrow$ \\
\hline & & & & & $\begin{array}{c}\text { Change } \\
\text { Direction } \\
\text { Ability }\end{array}$ & $\uparrow$ & PT MO C CG $\uparrow$ \\
\hline \multirow[t]{5}{*}{$\begin{array}{l}\text { Kobal et } \\
\text { al. } \\
2018(10)\end{array}$} & \multirow{5}{*}{$\begin{array}{l}\text { - Complex } \\
\text { Tr. } \\
\text { - Contrast } \\
\text { Tr. } \\
\text { - TST }\end{array}$} & \multirow{5}{*}{$\begin{array}{c}27 \text { men } \\
\text { footballer } \\
(18.9 \pm 0.6 \\
\text { Age })\end{array}$} & \multirow[t]{5}{*}{$\begin{array}{l}\text { Competition } \\
\text { Season }\end{array}$} & \multirow[t]{5}{*}{$\begin{array}{c}8 \mathrm{wk} / 2 \\
\text { day }\end{array}$} & $\begin{array}{l}\text { Maximum } \\
\text { Dynamic } \\
\text { Strength }\end{array}$ & $\uparrow$ & $\mathrm{COT} \leftrightarrow \mathrm{TST} \leftrightarrow$ \\
\hline & & & & & Vertical Jump & $\uparrow$ & $\mathrm{COT} \leftrightarrow \mathrm{TST} \leftrightarrow$ \\
\hline & & & & & Agility & $\leftrightarrow$ & $\mathrm{COT} \leftrightarrow \mathrm{TST} \leftrightarrow$ \\
\hline & & & & & $10 \mathrm{~m}$ sprint & $\uparrow$ & $\mathrm{COT} \leftrightarrow \mathrm{TST} \uparrow$ \\
\hline & & & & & $20 \mathrm{~m}$ sprint & $\uparrow$ & $\mathrm{COT} \leftrightarrow \mathrm{TST} \uparrow$ \\
\hline \multirow{4}{*}{$\begin{array}{l}\text { Al-Shafee } \\
2017 \text { (59) }\end{array}$} & \multirow{4}{*}{$\begin{array}{l}\text { - Contrast } \\
\text { Tr. } \\
\text { - Control } \\
\text { Group }\end{array}$} & \multirow{4}{*}{$\begin{array}{c}40 \text { men } \\
\text { footballer } \\
\text { (U17 } \\
\text { team) }\end{array}$} & \multirow[t]{4}{*}{$?$} & \multirow{4}{*}{$\begin{array}{c}10 \mathrm{wk} / 3 \\
\text { day }\end{array}$} & Vertical Jump & $\uparrow$ & $\mathrm{CG} \uparrow$ \\
\hline & & & & & Long Jump & $\uparrow$ & $\mathrm{CG} \uparrow$ \\
\hline & & & & & $\begin{array}{c}\text { Abdominal } \\
\text { Crunch Testing }\end{array}$ & $\uparrow$ & $\mathrm{CG} \uparrow$ \\
\hline & & & & & $\begin{array}{l}\text { Push-up (with } \\
\text { medical ball) }\end{array}$ & $\uparrow \uparrow$ & $\mathrm{CG} \uparrow$ \\
\hline \multirow{4}{*}{$\begin{array}{l}\text { Hammam } \\
\text { i et al } \\
2017(58)\end{array}$} & \multirow{4}{*}{$\begin{array}{l}\text { - Contrast } \\
\text { Tr. } \\
\text { - TST } \\
\text { - Control } \\
\text { Group }\end{array}$} & \multirow{4}{*}{$\begin{array}{c}44 \text { men } \\
\text { footballer } \\
(16.0 \pm \\
0.5 \text { Age })\end{array}$} & \multirow{4}{*}{$\begin{array}{l}\text { Competition } \\
\text { Season }\end{array}$} & \multirow{4}{*}{$\begin{array}{c}8 \mathrm{wk} / 2 \\
\text { day }\end{array}$} & $40 \mathrm{~m}$ sprint & $\uparrow$ & $\mathrm{TST} \leftrightarrow \mathrm{CG} \uparrow$ \\
\hline & & & & & $4 \times 5 \mathrm{~m}$ sprint & $\uparrow$ & $\mathrm{TST} \uparrow \mathrm{CG} \uparrow$ \\
\hline & & & & & $\begin{array}{l}\text { Repeated Sprint } \\
\text { Shuttle }\end{array}$ & $\leftrightarrow$ & TST C CG $\leftrightarrow$ \\
\hline & & & & & $\begin{array}{l}\text { 9-3-6-3-9 m } \\
\text { sprint tests }\end{array}$ & $\bar{\uparrow}$ & $\mathrm{TST} \leftrightarrow \mathrm{CG} \uparrow$ \\
\hline
\end{tabular}




\begin{tabular}{|c|c|c|c|c|c|c|c|}
\hline & & & & & $\begin{array}{c}\text { Repeated } \\
\text { Change } \\
\text { Direction Test }\end{array}$ & $\uparrow$ & $\mathrm{TST} \uparrow \mathrm{CG} \uparrow$ \\
\hline & & & & & Jump Tests & $\uparrow$ & $\mathrm{TST} \leftrightarrow \mathrm{CG} \uparrow$ \\
\hline \multirow{4}{*}{$\begin{array}{l}\text { Hammam } \\
\text { i et al } \\
2017(57)\end{array}$} & \multirow{4}{*}{$\begin{array}{l}\text { - Contrast } \\
\text { Tr. } \\
\text { - Control } \\
\text { Group }\end{array}$} & \multirow{4}{*}{$\begin{array}{l}28 \text { men's } \\
\text { footballer } \\
\text { (u17 } \\
\text { team) }\end{array}$} & \multirow{4}{*}{$\begin{array}{l}\text { Competition } \\
\text { Season }\end{array}$} & \multirow{4}{*}{$\begin{array}{c}8 \mathrm{wk} / 2 \\
\text { day }\end{array}$} & Sprint Tests & $\uparrow$ & CG ? \\
\hline & & & & & Agility Tests & $\uparrow$ & CG ? \\
\hline & & & & & $\begin{array}{c}\text { Repeated Sprint } \\
\text { Test }\end{array}$ & $\leftrightarrow$ & CG ? \\
\hline & & & & & $\begin{array}{c}\text { Repeated } \\
\text { Change } \\
\text { Direction } \\
\end{array}$ & $\bar{\uparrow}$ & CG? \\
\hline \multirow{3}{*}{$\begin{array}{l}\text { Spineti et } \\
\text { al } \\
2016(56)\end{array}$} & \multirow{3}{*}{$\begin{array}{c}\text { - Complex } \\
\text { Contrast Tr. } \\
\text { - TST }\end{array}$} & \multirow{3}{*}{$\begin{array}{c}22 \text { men's } \\
\text { footballer } \\
(18.4 \pm 0.4 \\
\text { Age })\end{array}$} & \multirow{3}{*}{$\begin{array}{l}\text { Competition } \\
\text { Season }\end{array}$} & \multirow{3}{*}{$\begin{array}{c}8 \mathrm{wk} / 3 \\
\text { day }\end{array}$} & Vertical Jump & $\uparrow$ & CG? \\
\hline & & & & & $\begin{array}{c}\text { Repeated } \\
\text { shuttle sprint }\end{array}$ & $\uparrow$ & CG? \\
\hline & & & & & $1 \mathrm{RM}$ & $\uparrow$ & CG? \\
\hline \multirow{4}{*}{$\begin{array}{c}\text { Felipe } \\
\text { García et } \\
\text { al. } \\
2014(17)\end{array}$} & \multirow{4}{*}{$\begin{array}{l}\text { - Contrast } \\
\text { Tr. } \\
\text { - Control } \\
\text { Group }\end{array}$} & \multirow{4}{*}{$\begin{array}{c}30 \text { men's } \\
\text { footballer } \\
(14-18 \\
\text { Age })\end{array}$} & \multirow[t]{4}{*}{ In-Season } & \multirow{4}{*}{$\begin{array}{c}12 \mathrm{wk} / 2 \\
\text { day }\end{array}$} & Vertical Jump & $\uparrow$ & $\mathrm{CG} \uparrow$ \\
\hline & & & & & Sprint & $\uparrow$ & $\mathrm{CG} \uparrow$ \\
\hline & & & & & Kicking Speed & $\uparrow$ & $\mathrm{CG} \uparrow$ \\
\hline & & & & & Agility & $\uparrow$ & $\mathrm{CG} \uparrow$ \\
\hline \multirow{6}{*}{$\begin{array}{l}\text { Faude et } \\
\text { al } 2013 \\
(55)\end{array}$} & \multirow{6}{*}{$\begin{array}{l}\text { Combined } \\
\text { Tr. } \\
\text { Control } \\
\text { Group }\end{array}$} & \multirow{6}{*}{$\begin{array}{c}16 \text { men } \\
\text { footballer } \\
(22.5 \pm 2.5 \\
\text { Age })\end{array}$} & \multirow{6}{*}{$\begin{array}{l}\text { Competition } \\
\text { Season }\end{array}$} & \multirow{6}{*}{$\begin{array}{c}7 \mathrm{wk} / 2 \\
\text { day }\end{array}$} & 1 RM Squat & $\uparrow$ & $\mathrm{CG} \uparrow$ \\
\hline & & & & & Sprint & $\leftrightarrow$ & $\mathrm{CG} \leftrightarrow$ \\
\hline & & & & & Agility & $\leftrightarrow$ & $\mathrm{CG} \leftrightarrow$ \\
\hline & & & & & Jump Height & $\uparrow$ & $\mathrm{CG} \uparrow$ \\
\hline & & & & & $\begin{array}{l}\text { Intermittent } \\
\text { Endurance }\end{array}$ & $\leftrightarrow$ & $\mathrm{CG} \leftrightarrow$ \\
\hline & & & & & $\begin{array}{c}\text { Isometric peak } \\
\text { power }\end{array}$ & $\leftrightarrow$ & $\mathrm{CG} \leftrightarrow$ \\
\hline \multirow{3}{*}{$\begin{array}{l}\text { Mujika et } \\
\text { al } \\
2009(16)\end{array}$} & \multirow{3}{*}{$\begin{array}{l}\text { - Contrast } \\
\text { Tr. } \\
\text { Sprint Tr. }\end{array}$} & \multirow{3}{*}{$\begin{array}{c}20 \text { men's } \\
\text { footballer } \\
(18.1 \pm 0.5 \\
18.5 \pm 0.7 \\
\text { Age })\end{array}$} & \multirow[t]{3}{*}{$\begin{array}{l}\text { Competition } \\
\text { Season }\end{array}$} & \multirow{3}{*}{$\begin{array}{c}7 \text { wk / } \\
\text { during 7- } \\
\text { week } 6 \\
\text { training }\end{array}$} & Vertical Jump & $\leftrightarrow$ & $\mathrm{CG} \leftrightarrow$ \\
\hline & & & & & $15 \mathrm{~m}$ sprint & $\leftrightarrow$ & $\mathrm{CG} \uparrow$ \\
\hline & & & & & $15 \mathrm{~m}$ agility & $\leftrightarrow$ & $\mathrm{CG} \leftrightarrow$ \\
\hline
\end{tabular}

Tr. $=$ Training $; \mathrm{m}=$ Meter; $\mathrm{wk}=$ Week $\mathrm{SAQ}=$ Speed, Agility and Quickness Training; COT= Complex Training; $\mathrm{CG}=$ Control Group; $\mathrm{PT}=$ Plyometric Training; TST= Traditional Strength Training; RM= Maximum Reps; $\leftrightarrow=$ No Significant Difference; $\uparrow=$ Positive Significant Difference; $\downarrow=$ Negative Significant Difference $?=$ Unspecified

Table.2. The Effect of Complex Training on Physical Parameters in Soccer

\begin{tabular}{|c|c|c|c|c|c|c|c|}
\hline Articles & Groups & $\begin{array}{l}\text { Subject } \\
\text { Type }\end{array}$ & Season & $\begin{array}{l}\text { Work } \\
\text { Time }\end{array}$ & $\begin{array}{l}\text { Researched } \\
\text { Parameters }\end{array}$ & $\begin{array}{l}\text { Contrast } \\
\text { Tr. Test } \\
\text { Results }\end{array}$ & $\begin{array}{c}\text { Complex Tr. } \\
\text { Against Other } \\
\text { Groups the Effect }\end{array}$ \\
\hline \multirow[t]{3}{*}{$\begin{array}{c}\text { Ali et al } \\
2019(54)\end{array}$} & \multirow{3}{*}{$\begin{array}{l}\text { - Complex Tr. } \\
\text { - Contrast Tr. } \\
\text { - Control Group }\end{array}$} & \multirow{3}{*}{$\begin{array}{l}36 \text { men's } \\
\text { footballer } \\
(18-25 \\
\text { Age })\end{array}$} & \multirow[t]{3}{*}{ ? } & \multirow[t]{3}{*}{$\begin{array}{c}6 \mathrm{wk} / 3 \\
\text { day }\end{array}$} & $20 \mathrm{~m}$ sprint & $\uparrow$ & $\begin{array}{c}\mathrm{CG} \uparrow \\
\mathrm{CT} ? \mathrm{sa} ?\end{array}$ \\
\hline & & & & & Agility & $\uparrow$ & $\begin{array}{c}\mathrm{CG} \uparrow \\
\mathrm{CT} ? \mathrm{sa} ?\end{array}$ \\
\hline & & & & & Vertical Jump & $\uparrow$ & $\begin{array}{c}\mathrm{CG} \uparrow \\
\mathrm{CT} ? \mathrm{sa} ?\end{array}$ \\
\hline \multirow[t]{7}{*}{$\begin{array}{c}\text { Chatzinikolao } \\
\text { u et al } \\
2018(67)\end{array}$} & \multirow[t]{7}{*}{$\begin{array}{l}\text { Complex Tr. } \\
\text { Control Group }\end{array}$} & \multirow{7}{*}{$\begin{array}{l}22 \text { men's } \\
\text { footballer } \\
(14-15 \\
\text { Age })\end{array}$} & \multirow[t]{7}{*}{$\begin{array}{l}\text { Transition } \\
\text { Season }\end{array}$} & \multirow[t]{7}{*}{$\begin{array}{c}5 \text { wk / } 4 \\
\text { day }\end{array}$} & $\begin{array}{c}\text { Jump Tests (DJ, } \\
\text { SJ, } \\
\text { CMJJ) }\end{array}$ & $\uparrow$ & $\mathrm{CG} \uparrow$ \\
\hline & & & & & $1 \mathrm{RM}$ & $\uparrow$ & $\mathrm{CG} \uparrow$ \\
\hline & & & & & $\begin{array}{c}\text { Change } \\
\text { Direction }\end{array}$ & $\leftrightarrow$ & $\mathrm{CG} \leftrightarrow$ \\
\hline & & & & & $10 \mathrm{~m}$ sprint & $\uparrow$ & $\mathrm{CG} \uparrow$ \\
\hline & & & & & $30 \mathrm{~m}$ sprint & $\leftrightarrow$ & $\mathrm{CG} \leftrightarrow$ \\
\hline & & & & & $\begin{array}{c}\text { Speed } \\
\text { Endurance }\end{array}$ & $\downarrow$ & $\mathrm{CG} \leftrightarrow$ \\
\hline & & & & & Repeated Sprint & $\leftrightarrow$ & $\mathrm{CG} \leftrightarrow$ \\
\hline \multirow{2}{*}{$\begin{array}{l}\text { Abdelkader } \\
2018(65)\end{array}$} & \multirow[t]{2}{*}{ Complex Tr. } & \multirow{2}{*}{$\begin{array}{l}10 \text { men's } \\
\text { footballer }\end{array}$} & & \multirow{2}{*}{$\begin{array}{c}8 \text { wk / } 4 \\
\text { day }\end{array}$} & Squat Jump & $\uparrow$ & $?$ \\
\hline & & & & & CMJ & $\uparrow$ & $?$ \\
\hline
\end{tabular}




\begin{tabular}{|c|c|c|c|c|c|c|c|}
\hline & & \multirow[t]{4}{*}{$\begin{array}{l}(20.7+/- \\
1.2 \text { Age })\end{array}$} & \multirow{4}{*}{$\begin{array}{c}\text { Special } \\
\text { Preparatio } \\
\text { n } \\
\text { Season }\end{array}$} & & $\begin{array}{c}\text { Ground Contact } \\
\text { Time }\end{array}$ & $\uparrow$ & $?$ \\
\hline & & & & & $\begin{array}{c}\text { Head Ball } \\
\text { Height }\end{array}$ & $\uparrow$ & $?$ \\
\hline & & & & & $\begin{array}{l}\text { Max. Time to } \\
\text { Reach Height }\end{array}$ & $\uparrow$ & $?$ \\
\hline & & & & & $\begin{array}{c}\text { Time to Stay } \\
\text { Air }\end{array}$ & $\uparrow$ & $?$ \\
\hline \multirow{4}{*}{$\begin{array}{l}\text { Wallenta et al } \\
2016(64)\end{array}$} & \multirow{4}{*}{$\begin{array}{l}\text { - Complex Tr. } \\
\text { - Block } \\
\text { Strength Tr. } \\
\text { Group }\end{array}$} & \multirow{4}{*}{$\begin{array}{c}12 \text { men's } \\
\text { footballer } \\
(18.5 \pm 2.2 \\
18.1 \pm 1.6)\end{array}$} & \multirow[t]{4}{*}{ In-Season } & \multirow{4}{*}{$\begin{array}{c}6 \mathrm{wk} / 2 \\
\text { day }\end{array}$} & Squat $1 \mathrm{RM}$ & $\uparrow$ & $\mathrm{BST} \leftrightarrow$ \\
\hline & & & & & CMJ & $\uparrow$ & $\mathrm{BST} \uparrow$ \\
\hline & & & & & Agility & $\uparrow$ & $\mathrm{BST} \leftrightarrow$ \\
\hline & & & & & $\begin{array}{c}5.10,30 \mathrm{~m} \\
\text { sprint }\end{array}$ & $\leftrightarrow$ & $\mathrm{BST} \downarrow$ \\
\hline \multirow{4}{*}{$\begin{array}{c}\text { Harsley } \\
2015(63)\end{array}$} & \multirow{4}{*}{$\begin{array}{l}\text { Complex Tr. } \\
\text { Control Group }\end{array}$} & \multirow{4}{*}{$\begin{array}{c}17 \text { men } \\
\text { footballer } \\
?\end{array}$} & \multirow[t]{4}{*}{$?$} & \multirow{4}{*}{$\begin{array}{c}10 \text { wk / } \\
2 \text { day }\end{array}$} & $40 \mathrm{~m}$ sprint & $\uparrow$ & $\mathrm{CG} \leftrightarrow$ \\
\hline & & & & & CMJ & $\uparrow$ & $\mathrm{CG} \uparrow$ \\
\hline & & & & & Agility & $\leftrightarrow$ & $\mathrm{CG} \leftrightarrow$ \\
\hline & & & & & $\begin{array}{l}\text { Medical Ball } \\
\text { Throw }\end{array}$ & $\uparrow$ & $\mathrm{CG} \leftrightarrow$ \\
\hline \multirow{3}{*}{$\begin{array}{c}\text { Franco- } \\
\text { Márquez et al } \\
2015(20)\end{array}$} & \multirow[t]{3}{*}{$\begin{array}{l}\text { Combined Tr. } \\
\text { Control Group }\end{array}$} & \multirow{3}{*}{$\begin{array}{l}38 \text { men } \\
\text { footballer } \\
\text { (15under } \\
\text { age })\end{array}$} & \multirow[t]{3}{*}{$?$} & \multirow[t]{3}{*}{$\begin{array}{c}6 \mathrm{wk} / 2 \\
\text { day }\end{array}$} & $\begin{array}{l}\text { Sprint Time }(10, \\
20 \text { meters }))\end{array}$ & $\uparrow$ & $\mathrm{CG} \uparrow$ \\
\hline & & & & & $\mathrm{CMJ}$ & $\uparrow$ & $\mathrm{CG} \uparrow$ \\
\hline & & & & & $1 \mathrm{RM}$ & $\uparrow$ & $\mathrm{CG} \uparrow$ \\
\hline \multirow{4}{*}{$\begin{array}{c}\text { Cavaco et al } \\
2014(39)\end{array}$} & \multirow{4}{*}{$\begin{array}{l}\text { Complex Tr.1 } \\
\text { Complex Trt.2 } \\
\text { Control Group }\end{array}$} & \multirow{4}{*}{$\begin{array}{c}16 \text { men's } \\
\text { footballer } \\
(13-15 \\
\text { Age })\end{array}$} & \multirow[t]{4}{*}{$?$} & \multirow{4}{*}{$\begin{array}{c}6 \mathrm{wk} / 1 \\
\text { or } 2 \\
\text { days }\end{array}$} & $15 \mathrm{~m}$ sprint & $\leftrightarrow$ & COT.2 C CG $\leftrightarrow$ \\
\hline & & & & & $\begin{array}{l}\text { Agility with } \\
\text { ball }\end{array}$ & $\leftrightarrow$ & COT.2 C CG $\leftrightarrow$ \\
\hline & & & & & Shot accuracy & $\uparrow$ & $\mathrm{COT} .2 \leftrightarrow \mathrm{CG} \uparrow$ \\
\hline & & & & & $\begin{array}{l}\text { Crossing } \\
\text { efficiency }\end{array}$ & $\leftrightarrow$ & COT.2 C CG $\leftrightarrow$ \\
\hline \multirow{4}{*}{$\begin{array}{l}\text { Brito et al } \\
2014(62)\end{array}$} & \multirow{4}{*}{$\begin{array}{l}\text { Complex Tr. } \\
\text { Plyometric Tr. } \\
\text { Strength Tr. } \\
\text { Control Group }\end{array}$} & \multirow{4}{*}{$\begin{array}{l}57 \text { men's } \\
\text { footballer } \\
(19-22 \\
\text { Age })\end{array}$} & \multirow[t]{4}{*}{ In-Season } & \multirow{4}{*}{$\begin{array}{c}9 \text { wk / } 2 \\
\text { day }\end{array}$} & $20 \mathrm{~m}$ sprint & $\uparrow$ & $?$ \\
\hline & & & & & $5 \mathrm{~m}$ sprint & $\leftrightarrow$ & $?$ \\
\hline & & & & & Agility & $\leftrightarrow$ & $?$ \\
\hline & & & & & Jump & $\leftrightarrow$ & $?$ \\
\hline \multirow{5}{*}{$\begin{array}{c}\text { Maio Alves et } \\
\text { al } \\
2010(27)\end{array}$} & & 23 men's & Pre- & $6 \mathrm{wk} / 1$ & $5 \mathrm{~m}$ sprint & $\uparrow$ & $\mathrm{CCT} 2 \leftrightarrow \mathrm{CG} \uparrow$ \\
\hline & Contrast En. 1 & footballer & Season & or 2 & $15 \mathrm{~m}$ sprint & $\uparrow$ & $\mathrm{CCT} 2 \leftrightarrow \mathrm{CG} \uparrow$ \\
\hline & Complex & $(17.4 \pm 0.6$ & & days & SJ & $\uparrow$ & $\mathrm{CCT} 2 \leftrightarrow \mathrm{CG} \uparrow$ \\
\hline & Contrast En. 2 & Age) & & & $\mathrm{CMJ}$ & $\leftrightarrow$ & CCT2 C CG $\leftrightarrow$ \\
\hline & & & & & Agility & $\leftrightarrow$ & CCT2 C CG ↔ \\
\hline Ronnestad et & - Strength+PLY & 21 men & Pre- & $7 \mathrm{wk} / 2$ & 1 RM Squat & $\uparrow$ & $\mathrm{TST} \leftrightarrow \mathrm{CG} \uparrow$ \\
\hline al 2008 (61) & Tr. & footballer & Season & day & CMJ & $\leftrightarrow$ & TST C CG $\leftrightarrow$ \\
\hline & - TST & $(23 \pm 2$ & & & SJ & $\uparrow$ & $\mathrm{TST} \leftrightarrow \mathrm{CG} \uparrow$ \\
\hline & - Control Group & $\begin{array}{c}22 \pm 2.5 \\
24 \pm 1.5 \\
\text { Age) }\end{array}$ & & & $\begin{array}{l}\text { Squat peak } \\
\text { power tests }\end{array}$ & $\uparrow$ & $\begin{array}{c}\text { TST } \leftrightarrow \\
\text { CG } \leftrightarrow(50 \mathrm{~kg} \\
\text { excluding })\end{array}$ \\
\hline & & & & & Sprint Tests & $\leftrightarrow$ & $\begin{array}{l}\mathrm{TST} \leftrightarrow \\
\mathrm{CG} \leftrightarrow\end{array}$ \\
\hline
\end{tabular}

Tr. $=$ Training $\mathrm{m}=$ Meter; PLY; Plyometric; BST; Block Strength Training; CT $=$ Contrast Training; $\mathrm{CCT} 2=$ Complex Contrast Training 2; Max. = Maximum; SJ= Squat Jump; CMJ $=$ Counter Movement Jump; CG= Control Group COT.2= Complex Training 2; RM= Maximum Reps; $\leftrightarrow=$ No Significant Difference; $\uparrow=$ Positive Significant Difference; $\downarrow=$ Negative Significant Difference; = Unspecified

\section{Discussion and Conclusion}

Contrast and complex training are based on the same theory and is formed by combining strength and plyometric training. Some researchers have expressed different opinions about these methods. This has led to confusion in subsequent studies. Two different names of training methods were investigated with the same definitions and the same training protocols. Based on the literature, some hypotheses can be developed that cause this confusion. For the first time in history, combining 
strength training and plyometric training has been expressed as complex training. The reason for this name is that Verkhoshansk, who is considered the founder of training methods, thinks that several complex changes occur in the body with this method. Based on this idea, Fleck and Kontor created a protocol called complex training (Fleck \& Kontor, 1986). But complex involves contrasting loads in itself in training. Therefore, the first hypothesis that can be formed is that the same training method is studied under two different names in the literature. According to this hypothesis, some researchers considered complex and contrast training to be the same training method and studied complex training under the name contrast training. Given that they are based on the same theory and contain similar loads within the same training unit, this hypothesis seems logical. But there are different opinions in terms of strength and the order in which you practice plyometric exercises. "Contrast and complex training are the same training methods" our hypothesis will be insufficient to clarify the debate in terms of different protocols at this stage. Another hypothesis that can also be developed for this is the idea of developing an existing training method with different sets and forms of practice. In this hypothesis, contrast training is an alternative method for complex training. In contrast to the opposite loads in set blocks, in this method, researchers may have wondered about the effect of plyometric exercise on various parameters after a one-set strength exercise. In this way, a new alternative protocol to complex training may be put forward with different forms of practice. From the point of view of football, it is worth noting that different protocols are created when studying contrast and complex training. The application of 3 different exercises consecutively as a single set has been frequently studied in football. In this protocol, researchers called contrast or complex training. However, this protocol does not comply with traditional contrast and complex training protocols. So that this protocol is not misunderstood by future researchers, the name "complex contrast training" by Maio Alves et al., (2010) can be used to define this protocol.

Contrast and complex many PAP factors determine the efficiency of training. However, the absence of the same training protocols makes it difficult to compare studies with each other. Despite this, some inferences can be reached with the study findings. The only study that failed to see an improvement in performance using contrast and complex training in football is Mujika et al. When the training protocols of the researchers are examined, it is seen that only 6 units of training were performed for 7 weeks. This training number remains very low compared to other studies. At the same time, the content of the protocol is also designed in a different way than the contrasting training described in the literature. For these reasons, it seems possible that development cannot be achieved. It has been proven by many studies that contrast and complex training practices in football improve the strength, sprint, and vertical jump characteristics of subjects. But there is uncertainty, especially in the repetitive sprint and agility parameters. Many studies have not found a significant difference in these parameters. No research measuring agility performance has put an exercise suitable for this parameter. In studies, a classic strength exercise was followed by plyometric exercises or shortdistance flat sprint exercises. For the development of agility performance, changes in direction, uncertain stimuli are needed. Therefore, it is possible that no significant difference can be found as a result of research. In the same way, a significant difference in performance can be seen as the indirect effect of different biomotor abilities, athletes' training histories, and plyometric studies. It is stated in the study of Özbay et al. that these factors affect agility (Ozbay et al., 2018). In studies conducted on determining the frequency of optimal training for football, there was no significant difference between performing 1 or 2-day training methods. Training protocols were usually initiated with strength exercises ranging from $70-90 \%$ of $1 \mathrm{TM}$. But performing a strength exercise with violence between $45-60 \%$ of $1 \mathrm{TM}$ in young footballers was enough to improve various parameters. In the same way, $60-70 \%$ of $1 \mathrm{TM}$ is found in researchers who have developed research parameters by performing strength exercises. In this case, it is worth noting that strength exercise should be applied according to the individual characteristics of athletes. Moreover, it can be concluded that it is not necessary to perform a strength exercise at a very high intensity (80-90\% of $1 \mathrm{TM}$ ) before plyometric exercise. An important indicator of the impact of contrast and complex training on performance in football is comparisons with other groups. Although these methods made a significant difference to control groups that did not do weight training, they did not make a significant difference in most studies against other groups that did weight training. This raises questions about the impact of contrast and complex training on other strength training. 
Another topic of discussion is the PAP theory on which contrast and complex training are based. So far, PAP has been expressed as an increase in performance after a high-intensity pre-load exercise. But researchers who argue that this definition is not correct to have come up with a new concept called post-activation performance enhancement (PAPE) over the past few years. According to the researchers, post-activation potentiation refers to an increase in the twitching power of electrical stimuli that will perform novelization. PAPE, on the other hand, indicates an increase in parameters such as strength, strength, and sprint following a high-intensity voluntary novelization of the muscle (Blazevich \& Babault, 2019; Prieske et al., 2020). Researchers claim that various physiological variables such as muscle temperature, muscle $\mathrm{pH}$, and intracellular fluids can also influence this theory (Blazevich \& Babault, 2019). Further research on PAPE is needed. Its widespread use in the literature is a factor that will also affect the contrast and complex training.

As a result, contrast and complex training can be seen as similar training methods because it involves similar loads and is based on the same theory. Looking at training protocols in terms of the first study and subsequent studies is the right approach for us. In this respect, complex training is to apply a set block plyometric exercise biomechanically similar to this strength exercise after a set block strength exercise (2-3 sets). Contrast training is an alternative to complex training in this direction and is a one-set plyometric exercise that is biomechanically similar to this strength exercise after a one-set strength exercise.

In football, contrast and complex training can be seen as useful strength training for strength, strength, sprint, and jump abilities. Also, research with similar training protocols is needed to determine the effectiveness of these methods, as well as subjects of a similar nature. As studies increase in the following years, more precise conclusions will be reached about the efficiency of these training methods.

\section{References}

Abdelkader, M. A. (2018). Effect of Complex Training on Jumping variants During Heading the Ball for Soccer Players. International Sports Science Alexandria Journal, 1 (1), 1-14.

Ali, K., Verma, P., Ahmad, I., Singla, D., Saleem, M., \& Hussain, M. E. (2019). Comparison of complex versus contrast training on steroid hormones and sports performance in male soccer players. Journal of Chiropractic Medicine, 18(2), 131-138.

Al-Shafee, A. A. (2017). The effect of using contrast training during the pre-season period on the level of ability of muscle in junior football players. The International Scientific Journal of Physical Education and Sport Sciences, 5(1), 16-28.

Alves, J.. M. V. M., Rebelo, A. N., Abrantes, C., \& Sampaio, J. (2010). Short-term effects of complex and contrast training in soccer players' vertical jump, sprint, and agility abilities. The Journal of Strength \& Conditioning Research, 24(4), 936-941.

Baker, D. (1995). Selecting the appropriate exercises and loads for speed-strength development. Strength Coach, 3 (2), 8-16.

Blazevich, A. J., \& Babault, N. (2019). Post-activation potentiation (PAP) versus post-activation performance enhancement (PAPE) in humans: Historical perspective, underlying mechanisms, and current issues. Frontiers in Physiology, 10, 1359.

Bloomfield, J.., Polman, R., \& O'donoghue, P. (2007). Physical demands of different positions in FA Premier League soccer. Journal of sports science \& medicine, 6 (1), 63.

Bompa, T. O., \& Buzzichelli, C. (2018). Periodization -: theory and methodology of training. Human kinetics.

Brito, J., Vasconcellos, F., Oliveira, J., Krustrup, P., \& Rebelo, A. (2014). Short-term performance effects of three different low-volume strength-training programs in college male soccer players. Journal of human kinetics, 40 (1), 121-128.

Cavaco, B., Sousa, N., Dos Reis, V. M., Garrido, N., Saavedra, F., Mendes, R., \& Vilaça-Alves, J. (2014). Short-term effects of complex training on agility with the ball, speed, efficiency of crossing and shooting in youth soccer players. Journal of human kinetics, 43 (1), 105-112.

Chatzinikolaou, A., Michaloglou, K., Avloniti, A., Leontsini, D., Mad, C. K., Vlachopoulos, D., ... \& Jamurtas, A. Z. (2018). The trainability of adolescent soccer players to brief periodized 
complex training. International journal of sports physiology and performance, 13(5), 645655.

Cormier, P., Freitas, T. T., Rubio-Arias, J. Á., \& Alcaraz, P. E. (2020). Complex and Contrast Training: Does Strength and Power training Sequence Affect Performance-Based Adaptations in Team Sports? A Systematic Review and Meta-analysis. The Journal of Strength \& Conditioning Research, 34(5), 1461-1479.

Dobson, P., Goddard, J. A., \& Dobson, P. (2001). The economics of football (pp. 106-130). Cambridge: Cambridge University Press.

Docherty, D., Robbins, D., \& Hodgson, M. (2004). Complex training revisited: a review of its current status as a viable training approach. Strength and Conditioning Journal, 26 (6), 52.

Duthie, G. M., Young, W. B., \& Aitken, D. A. (2002). The acute effects of heavy loads on jump squat performance: an evaluation of the complex and contrast methods of power development. The Journal of Strength \& Conditioning Research, 16(4), 530-538.

Ebben, W. P. (2002). Complex training: a brief review. Journal of sports science \& medicine, 1 (2), 42.

Edge, J.., Hill-Haas, P., Goodman, C., \& Bishop, D. (2006). Effects of resistance training on H+ regulation, buffer capacity, and repeated sprints. Medicine \& Science in Sports \& Exercise, 38(11), 2004-2011.

Eniseler, N. (2017). Football Practice In The Light Of Science. Manisa: Celal Bayar University Press.

Faude, O., Roth, R., Di Giovine, D., Zahner, L., \& Donath, L. (2013). Combined strength and power training in high-level amateur football during the competitive season: a randomizedcontrolled trial. Journal of sports sciences, 31(13), 1460-1467.

Ferley, D. D., Scholten, P., \& Vukovich, M. D. (2020). Combined Sprint Interval, Plyometric, and Strength Training in Adolescent Soccer Players: Effects on measures of Speed, Strength, Power, Change of Direction, and Anaerobic Capacity. The Journal of Strength \& Conditioning Research, 34(4), 957-968.

Fleck, P., \& Kontor, K. (1986). Soviet strength and conditioning: Complex training. Strength \& Conditioning Journal, 8 (5), 66-72.

Franco-Márquez, F., Rodríguez-Rosell, D., González-Suárez, J. M., Pareja-Blanco, F., MoraCustodio, R., Yañez-García, J. M., \& González-Badillo, J. J. (2015). Effects of combined resistance training and plyometrics on physical performance in young soccer players. International journal of sports medicine, 94(11), 906-914.

García-Pinillos, F., Martínez-Amat, A., Hita-Contreras, F., Martínez-López, E. J., \& LatorreRomán, P. A. (2014). Effects of a contrast training program without external load on vertical jump, kicking speed, sprint, and agility of young soccer players. The Journal of Strength \& Conditioning Research, 28(9), 2452-2460.

Hammami, M., Gaamouri, N., Shephard, R. J., \& Chelly, M. S. (2019). Effects of contrast strength vs. plyometric training on lower-limb explosive performance, ability to change direction and neuromuscular adaptation in soccer players. The Journal of Strength \& Conditioning Research, 33(8), 2094-2103.

Hammami, M., Negra, P., Shephard, R. J., \& Chelly, M. S. (2017a). Effects of leg contrast strength training on sprint, agility and repeated change of direction performance in male soccer players. The Journal of sports medicine and physical fitness, 57(11), 1424.

Hammami, M., Negra, P., Shephard, R. J., \& Chelly, M. S. (2017b). The effect of standard strength vs. contrast strength training on the development of sprint, agility, repeated change of direction, and jump in junior male soccer players. Journal of strength and conditioning research, 31(4), 901-912.

Harsley, P., Bishop, D., \& Gee, T. (2015). The effect of a 10-week complex training program, utilising optimal PAP recovery time, on the sprint, power and agility capabilities of elite academy footballers.

Heckman, C. J., \& Enoka, R. M. (2012). Motor unit. Comprehensive physiology, 2 (4), 2629-2682.

Hodgson, M., Docherty, D., \& Robbins, D. (2005). Post-activation potentiation. Sports medicine, 35 (7), 585-595.

Ingle, L., Sleap, M., \& Tolfrey, K. (2006). The effect of a complex training and detraining program on selected strength and power variants in early puberty boys. Journal of sports sciences, 24(9), 987-997. 
Jovanovic, M., Sporis, G., Omrcen, D., \& Fiorentini, F. (2011). Effects of speed, agility, quickness training method on power performance in elite soccer players. The Journal of Strength \& Conditioning Research, 25(5), 1285-1292.

Karabiyık, A. (2018). The effect of complex strength training on anaerobic strength performances of young footballers (Master's thesis, Istanbul Development University Institute of Health Sciences).

Karaday, E. (2018). Acute effect of preloading at different loads on active jump and sprint performance in young football players (Master's thesis, Pamukkale University Institute of Health Sciences).

Kobal, R., Loturco, I., Barroso, R., Gil, P., Cuniyochi, R., Ugrinowitsch, C., ... \& Tricoli, V. (2017). Effects of different combinations of strength, power, and plyometric training on the physical performance of elite young soccer players. The Journal of Strength \& Conditioning Research, 31(6), 1468-1476.

Lagrange, P., Ferland, P. M., Leone, M., \& COMTOIS, a. S. (2020). Contrast Training Generates Post-Activation Potentiation and Improves Repeated Sprint Ability in Elite Ice Hockey Players. International Journal of Exercise Science, 13(6), 183.

Latorre Román, P. Á., Villar Macias, F. J., \& García Pinillos, F. (2018). Effects of a contrast training program on jumping, sprinting and agility performance of prepubescent basketball players. Journal of sports sciences, 36(7), 802-808.

Mihalik, J.. P., Libby, J. J., Battaglini, C. L., \& McMurray, R. G. (2008). Comparing short-term complex and compound training programs on vertical jump height and power output. The Journal of Strength \& Conditioning Research, 22(1), 47-53.

Mishra, M. K., \& Rathore, V. S. (2016). Speed and agility as predictors of long jump performance of male athletes. English J Sport Exerc, 18, 27-33.

Mujika, I., Santisteban, J., \& Castagna, C. (2009). In-season effect of short-term sprint and power training programs on elite junior soccer players. The Journal of Strength \& Conditioning Research, 23(9), 2581-2587.

Nuzzo, J. L., Barry, B. K., Gandevia, P. C., \& Taylor, J. L. (2016). Acute Strength Training Increases Responses to Stimulation of Corticospinal Axons. Medicine and science in sports and exercise, 48(1), 139-150.

Ozbay, P., Ulupınar, P., \& Ozkara, A. B. (2018). Agility Performance In Sports. National Journal Of Sports Science, 2 (2), 97-112.

Pajerska, K., Zajac, T., Mostowik, A., Mrzyglod, P., \& Golas, A. (2020). Post activation potentiation (PAP) and its application in the development of speed and explosive strength in female soccer players: a review.

Prieske, O., Behrens, M., Chaabene, H., Granacher, U., \& Maffiuletti, N. A. (2020). Time to differ from Postactivation" Potentiation "to" Performance Enhancement " in the Strength and Conditioning Community. Sports Medicine (Auckland, NZ).

Rampinini, E., Sassi, A., Azzalin, A., Castagna, C., Menaspa, P., Carlomagno, D., \& Impellizzeri, F. M. (2010). Physiologic determinants of Yo-Yo intermittent recovery tests in male soccer players. European journal of applied physiology, 108(2), 401.

Rassier, D. E., Tubman, L. A., \& MacIntosh, B. R. (1999). Staircase in mammalian muscle without light chain phosphorylation. Brazilian Journal of Medical and Biological Research, 32(1), 121-130.

Requena, B., Zabala, M., Ribas, J., Ereline, J., Paasuke, M., \& Gonzalez-Badillo, J. J. (2005). Effect of post-tetanic potentiation of pectoralis and triceps brachii muscles on bench press performance. Journal of Strength and Conditioning Research, 19(3), 622.

Ronnestad, B. R., Kvamme, N. H., Sunde, A., \& Raastad, T. (2008). Short-term effects of strength and plyometric training on sprint and jump performance in professional soccer players. The Journal of Strength \& Conditioning Research, 22(3), 773-780.

Roussos, A. (2019). Effects of combined isometric followed by plyometric exercise on vertical jump performance of soccer players.

Sahir, M. (2019). A Comparative study to Analyze the effectiveness of Contrast training program and Speed Agility training on Agility Performance of Elite Male Football Players (Doctoral dissertation, Cherraan's College of Physiotherapy, Coimbatore). 
Santos, E. J., \& Janeira, M. A. (2008). Effects of complex training on explosive strength in adolescent male basketball players. The Journal of Strength \& Conditioning Research, 22(3), 903-909.

Seitz, L. B., \& Haff, G. G. (2016). Factors modulating post-activation potentiation of jump, sprint, throw, and upper-body ballistic performances: A systematic review with meta-analysis. Sports Medicine, 46 (2), 231-240.

Shephard, R. J. (2015). An illustrated history of health and fitness, from pre-history to our postmodern world (pp. 1-1057). New York, NY: Springer.

Shepherd, O. (2019). Effect of complex training potentiation on reactive strength index parameters (Master's Thesis, Institute of Health Sciences).

Silva, J. R., Nassis, G. P., \& Rebelo, A. (2015). Strength training in soccer with a specific focus on highly trained players. Sports medicine-open, 1 (1), 17.

Spineti, J., Figueiredo, T., Bastos, V. D. O., Assis, M., Fernandes, L. D. O., Miranda, H., ... \& Simao, R. (2016). Comparison between traditional strength training and complex contrast training on repeated sprint ability and muscle architecture in elite soccer players. The Journal of sports medicine and physical fitness, 56(11), 1269-1278.

Stasinak, A. N., Gloumis, G., Spengos, K., Blazevich, A. J., Zaras, N., Georgiadis, G., ... \& Terzis, G. (2015). Muscle strength, power, and morphologic adaptations after 6 weeks of compound etc. complex training in healthy men. The Journal of Strength \& Conditioning Research, 29(9), 2559-2569.

Stølen, T., Chamari, K., Castagna, C., \& Wisløff, U. (2005). Physiology of soccer. Sports medicine, 35 (6), 501-536.

Suchomel, T. J., Nimphius, P., \& Stone, M. H. (2016). The importance of muscular strength in athletic performance. Sports medicine, 46 (10), 1419-1449.

Thomas, K., French, D., \& Hayes, P. R. (2009). The effect of two plyometric training techniques on muscular power and agility in youth soccer players. The Journal of Strength \& Conditioning Research, 23(1), 332-335.

Tillin, N. A., \& Bishop, D. (2009). Factors modulating post-activation potentiation and its effect on performance of subsequent explosive activities. Sports medicine, 39 (2), 147-166.

Treeraj, A., Kamutsri, T., Lawsirat, C., \& Intiraporn, C. (2016). Matching physical Demand of Competitive Soccer Matches with Comprehensive Complex Training for Soccer Players. Journal of Exercise Physiology Online, 19 (6).

Tsolakis, C., Bogdanis, G. C., Nikolaou, A., \& Zacharogiannis, E. (2011). Influence of type of muscle contraction and gender on postactivation potential of upper and lower limb explosive performance in elite fencers. Journal of sports science \& medicine, 10 (3), 577.

Turner, A. N., \& Stewart, P. F. (2014). Strength and Conditioning for Soccer Players. Strength and Conditioning Journal, 36 (4), 1-13.

Turner, A., Walker, P., Stembridge, M., Coneyworth, P., Reed, G., Birdsey, L., ... \& Moody, J. (2011). A testing battery for the assessment of fitness in soccer players. Strength \& Conditioning Journal, 33 (5), 29-39.

Übellacker, F. (2017). The combination of strength and power training to enhance athletic sports

Walker, O. (2016). Need Analysis. https://www.scienceforsport.com/needs-analysis/ access from the page.

Wallenta, C., Granacher, U., Lesinski, M., Schünemann, C., \& Muehlbauer, T. (2016). Effects of complex versus block strength training on the athletic performance of elite youth soccer players. Sportverletzung Sportschaden: Organ der Gesellschaft fur OrthopadischTraumatologische Sportmedizin, 30(1), 31-37.

Young, W. B., Jenner, A., \& Griffiths, K. (1998). Acute enhancement of power performance from heavy load squats. The Journal of Strength \& Conditioning Research, 12(2), 82-84.

Zghal, F., Colson, P. S., Blain, G., Behm, D. G., Granacher, U., \& Chaouachi, A. (2019). Combined Resistance and Plyometric Training Is More Effective Than Plyometric Training Alone for Improving Physical Fitness of adolescent Soccer Players. Frontiers in physiology, 10, 1026. 